\title{
Physiological Responses of Callus from Gerbera jamesonii Bolus ex. Hook f. to Gamma Irradiation
}

\author{
Nor Azlina Hasbullah ${ }^{1}$, Rosna Mat Taha ${ }^{2}$, Azani Saleh $^{3}$ and Normadiha Mohamed ${ }^{2}$ \\ ${ }^{1}$ Department of Agricultural Sciences; Faculty of Technical and Vocational Education; Sultan Idris Education \\ University; 35900; Tanjung Malim; Perak- Malaysia. .2 Institute of Biological Sciences; Faculty of Science; \\ University of Malaya; 50603; Kuala Lumpur- Malaysia. ${ }^{3}$ International Education Centre (INTEC); MARA \\ University of Technology; Section 17 Campus; 40200; Shah Alam; Selangor - Malaysia
}

\begin{abstract}
In the present study, in vitro mutagenesis techniques were applied to investigate the effects of gamma irradiation at $0,10,20,30,40,50$ and 60 Gy on physiological changes in callus of Gerbera jamesonii Bolus ex. Hook $f$. Biochemical changes in chlorophyll and soluble protein content of pre-and post-irradiated Gerbera callus were studied. Non-irradiated callus demonstrated the highest amount of chlorophyll content as compared to callus irradiated at 10, 20, 30, 40, 50 and $60 \mathrm{~Gy}$. In addition, the amount of chlorophyll $b$ was relatively higher than chlorophyll $a$ in both the irradiated and non-irradiated callus, except for callus irradiated at 10 Gy. Biochemical differentiation based on total soluble protein content revealed gradual reduction after day 9 of exposure to gamma irradiation. Reduction of soluble protein content was observed in all the treatments as the increase of incubation period.
\end{abstract}

Key words: Gerbera jamesonii, gamma irradiation, callus, in vitro, chlorophyll, soluble protein

\section{INTRODUCTION}

The methods of plant breeding have become increasingly sophisticated since the days of simple selection among the natural populations, which consisted of mixtures of genotypes. Modern day plant breeding is based on creating variation, selection, evaluation and multiplication of desired genotypes. To increase the efficiency and to cut short the time taken in each step, several techniques have been combined. Plant breeders have the options of using in vitro culture for rapid multiplication, molecular methods to select the specific genotypes, mutagenesis to enhance the variation, controlled environmental conditions to manipulate the growth and flowering and many others. Mutations induction could be done by either exposing the explants to the chemicals such as colchicine and ethylmethanesulphate or by physical mutagens such as irradiation using gamma and X-ray. The most preferred method to induce the mutation breeding is by irradiation. Irradiation technique can influence the changes of plant phenotype such as plants heights and growths, flower colours and sizes as well as the patterns and colours of the leaves.

The use of nuclear techniques in plant breeding has been mostly directed for inducing the mutations. Since the discovery of X-rays, the use of ionizing radiation such as $\mathrm{X}$-rays, gamma rays and neutrons for inducing the variation has become an established technology. Induced mutations have been used in the improvement of major crops such as wheat, barley, rice, cotton,

*Author for correspondence: azahhas@yahoo.com 
peanuts and beans which are seed propagated. Many induced mutants have been released as the cultivars and several others have been used as parents in the pedigree of some leading cultivars (Ahloowalia and Maluszynski 2001). In vegetatively propagated plants, many mutants in the ornamentals plants such as Achimenes, chrysanthemum, carnation, roses and Streptocarpus were obtained by irradiating the rooted stem cuttings, detached leaves and dormant plants (Broertjes 1977). The altered flower colour and shape, growth habit (dwarf or trailing) and other novel phenotype of commercial value were selected. According to the FAO/IAEA (Maluszynski et al. 1992), of the 465 mutants release among the vegetatively propagated plants, most have been floricultural plants and only a few fruit trees. These included chrysanthemums, Alstroemeria, dahlia, bougainvillea, rose, Achimenes, begonia, carnation, Streptocarpus and azalea. Since the effect of mutation in the ornamentals is very visible, the selection for changed flower colour, shape and size is easy. Hence, mutation techniques have become a major tool for breeding the ornamental plants (Maluszynski et al. 1995). The key factor in the irradiation of plant material is the dose, which is the amount of radiation energy absorbed by the material. The unit of measurement of radiation dose is Gray (Gy). Normally, high doses are used for sterilization purposes and low doses are used for mutations in plant materials.

Gerbera jamesonii Bolus ex. Hook f. is a flowering perennial plant which belongs to the Asteraceae family. It is a very well known plant and useful as cut flowers, pot crops and bedding plants. It is popularly known as 'Barberton daisy' or 'Transvaal daisy'. Gerberas are mostly found in temperate countries. However, it is proven that this plant could be successfully planted in tropical countries such as Malaysia. Through plant tissue culture technique, micropropagation of $G$. jamesonii could be obtained successfully. To-date, there is no major report on the use of gamma irradiation as a physical mutagen to alter the the physiological characteristics of $G$. jamesonii. Thus, the aim of the present study was to study the physiological changes on the callus of $G$. jamesonii after exposure to different doses of gamma irradiation.

\section{MATERIALS AND METHODS Gamma Radiation}

The gamma radiation treatment was obtained from ${ }^{60}$ Cobalt, 0026 Pool Irradiator with isotope model located at Physics Department, Faculty of Science, University of Malaya, Kuala Lumpur, Malaysia. The gamma dose rate was $0.204 \mathrm{~Gy} / \mathrm{second}$ at the time the experiment was conducted. The doses applied in this study were 10, 20, 30, 40, 50 and 60 Gy. After irradiation, the callus tissues were transferred and maintained in a fresh new MS (Murashige and Skoog, 1962) basal medium and maintained at $25 \pm 1{ }^{\circ} \mathrm{C}$ with the photoperiod of 16 $\mathrm{h}$ light and $8 \mathrm{~h}$ dark.

\section{Determination of Chlorophyll Content}

The chlorophyll contents for the irradiated and non-irradiated callus were determined according to Lichtenthaler (1987). Fresh callus (2.0g) obtained from the leaf explants cultured on MS (Murashige and Skoog, 1962) medium supplemented with 1.0 $\mathrm{mg} / \mathrm{L} \mathrm{BAP}$ and $2.0 \mathrm{mg} / \mathrm{L} \mathrm{2,} \mathrm{4-D} \mathrm{were} \mathrm{exposed} \mathrm{to}$ gamma irradiation (0-60 Gy). Irradiated callus was incubated for seven days to study the effect of irradiation on chlorophyll content in callus tissues. Two grams of callus was homogenized using a chilled mortar and pestle containing $10 \mathrm{ml}$ of $80 \%$ $(\mathrm{v} / \mathrm{v})$ acetone and some $\mathrm{MgCO}_{3}$. The sample extract was collected and filtered with Buchner funnel through Whatman filter paper. The extraction volume was topped up to $50 \mathrm{ml}$ with $80 \%$ (v/v) acetone. Callus tissues were carefully ground while being kept chilled. The samples were extracted in a dark environment to prevent the chlorophyll degradation. Samples were centrifuged for 5 minutes at 200-300 g. Adsorption were measured at 646 and $663 \mathrm{~nm}$ using a Shimadzu spectrophotometer. The chlorophyll a $\left(\mathrm{C}_{\mathrm{a}}\right)$ and chlorophyll $b\left(C_{b}\right)$ content in milligram per liter was determined according to the formula as below and expressed in milligram per gram fresh weight of plant material.

Chlorophyll a, $\mathrm{C}_{\mathrm{a}}=12.25\left(\mathrm{~A}_{663}\right)-2.79\left(\mathrm{~A}_{646}\right)$

Chlorophyll b, $\mathrm{C}_{\mathrm{b}}=21.50\left(\mathrm{~A}_{646}\right)-5.10\left(\mathrm{~A}_{663}\right)$

Total chlorophyll, $\mathrm{C}_{\mathrm{a}+\mathrm{b}}=7.15\left(\mathrm{~A}_{663}\right)+18.71\left(\mathrm{~A}_{646}\right)$

\section{Determination of Total Soluble Protein}

Total soluble protein content of the irradiated and non-irradiated callus was determined using Bradford (1976) method. The irradiated and nonirradiated callus was homogenized in ice bath with 
protein extraction buffer of the ratio of $1.0 \mathrm{~g}$ sample to $3.0 \mathrm{ml}$ of protein extraction buffer. The extracts were centrifuged at $12000 \mathrm{rpm}$ for 20 minutes at $4{ }^{\circ} \mathrm{C}$. In order to determine the total soluble protein content, $20 \mu \mathrm{l}$ of the sample extract was added into $80 \mu \mathrm{l}$ of protein extraction buffer and $5.0 \mathrm{ml}$ of protein reagent. The mixture was mixed by vortexing. Meanwhile, $20 \mu 1$ of double distilled water and $80 \mu 1$ of protein extraction buffer added with $5.0 \mathrm{ml}$ of protein reagent was used as the blank. The absorbance at $595 \mathrm{~nm}$ was determined using the Shimadzu spectrophotometer and compared with the standard curve plotted using bovine serum albumin (BSA) as the standard and expressed in microgram per gram fresh weight of the plant material.

\section{Statistical analysis}

In this study, three replicates were conducted for the physiological changes and the experiments were repeated twice. The results of physiological changes of the irradiated and non-irradiated callus of G. jamesonii were subjected to statistical analysis using one-way ANOVA and Duncan's Multiple Range Test (DMRT) using SPSS software (version 17.0) at $\mathrm{p}=0.05$.

\section{RESULTS AND DISCUSSION}

\section{Determination of Chlorophyll Content}

The biochemical changes based on chlorophyll content of the irradiated and non-irradiated callus tissues were obtained after one week of culture. Gamma irradiation induces various physiological and biochemical alterations in plants. The irradiation of the plants with high dosage of gamma rays disturbs the hormone balance, leaf gas-exchange, water exchange and enzyme activity (Stoeva 2002). Photosynthetic pigments can be destroyed by gamma irradiation with concomitant loss of photosynthetic capacity (Strid et al. 1990). Powell and Griffith (1963) stated that the ionizing radiation accelerated the degradation of chlorophyll in many plant species. In the present study, gamma irradiation accelerated the degradation of chlorophyll in callus cultures of $G$. jamesonii. According to Giacomelli et al. (1967), the irradiation accelerated the degradation of chlorophyll in barley leaves. Irradiation also caused some breakdown of the chloroplastic organization, resulting more readily degradation of chlorophill. They reported that the primary effect of irradiation was on the development of meristematic cells and the effect of auxin supply could be a consequence of the same. Hagen and Gunckel (1958) and Kuzin (1956) stated that the alteration in chlorophyll synthesis in the irradiated Nicotiana glauca and Nicotiana Langsdorfii tissues could be due to the auxin synthesis.

As shown in Table 1, all the irradiated callus tissues exhibited lower amount of chlorophyll a and $\mathrm{b}$ as compared to the non-iradiated callus, 83.2 $\pm 1.0 \mathrm{mg} / \mathrm{g}$. It was observed that as the irradiation dose increased, the degradation of chlorophyll was expressed. Callus irradiated at 10, 20 and 30 Gy exhibited total chlorophyll content of $82.6 \pm 1.7$, $79.8 \pm 2.0$ and $76.2 \pm 1.5 \mathrm{mg} / \mathrm{g}$, respectively but were not significantly different from one another. Callus irradiated at 40,50 and $60 \mathrm{~Gy}$ exhibited total chlorophyll content of $69.3 \pm 1.2,64.6 \pm 1.0$, $61.4 \pm 1.0 \mathrm{mg} / \mathrm{g}$, respectively which was significantly different as compared to the nonirradiated callus. The lowest total chlorophyll content was observed in the plantlet irradiated at 60 Gy. Callus irradiated at 40, 50 and $60 \mathrm{~Gy}$ demonstrated a reduction of 16.71, 22.36 and $26.2 \%$, respectively in total chlorophyll content as compared to the non-irradiated callus. Apparently, the content of the chlorophyll b was relatively higher than the chlorophyll a in both irradiated and non-irradiated callus, except for the callus irradiated at $10 \mathrm{~Gy}$. The reduction of chlorophyll a was due to more selective destruction of chlorophyll a biosynthetis of degradation of chlorophyll a precursors. In the present study, the chlorophyll content showed irregular distribution among the irradiated callus. Lower chlorophyll content was obtained from the irradiated callus compared to non-irradiated callus. This result was in agreement with Kim et al. (2004) where chlorophyll was visually insensitive to low doses gamma irradiation. 
Table 1- Chlorophyll a, Chlorophyll b and Total Chlorophyll Content of Irradiated Callus of Gerbera jamesonii at different doses of Gamma irradiation

\begin{tabular}{cccc}
\hline $\begin{array}{c}\text { Gamma Radiation } \\
\text { (Gy) }\end{array}$ & $\begin{array}{c}\text { Chlorophyll a } \\
(\mathbf{m g} / \mathbf{g})\end{array}$ & $\begin{array}{c}\text { Chlorophyll b } \\
(\mathbf{m g} / \mathbf{g})\end{array}$ & $\begin{array}{c}\text { Total Chlorophyll } \\
\text { Content }(\mathbf{m g} / \mathbf{g})\end{array}$ \\
\hline $\mathbf{0}$ (control) & $37.5 \pm 1.1$ & $45.7 \pm 0.6$ & $83.2 \pm 1.0_{\mathrm{a}}$ \\
$\mathbf{1 0}$ & $42.8 \pm 2.4$ & $39.8 \pm 0.9$ & $82.6 \pm 1.7_{\mathrm{a}, \mathrm{b}}$ \\
$\mathbf{2 0}$ & $36.2 \pm 2.6$ & $43.6 \pm 1.2$ & $79.8 \pm 2.0_{\mathrm{b}}$ \\
$\mathbf{3 0}$ & $35.5 \pm 0.8$ & $40.7 \pm 2.1$ & $76.2 \pm 1.5_{\mathrm{b}}$ \\
$\mathbf{4 0}$ & $28.3 \pm 1.7$ & $41.0 \pm 0.6$ & $69.3 \pm 1.2_{\mathrm{c}}$ \\
$\mathbf{5 0}$ & $26.3 \pm 0.3$ & $38.3 \pm 1.7$ & $64.6 \pm 1.0_{\mathrm{c}, \mathrm{d}}$ \\
$\mathbf{6 0}$ & $24.9 \pm 1.2$ & $36.5 \pm 1.0$ & $61.4 \pm 1.3_{\mathrm{d}}$ \\
\hline
\end{tabular}

Mean \pm SE, $n=30$. Mean with different letters in the same column differ significantly at $\mathrm{p}=0.05$

\section{Determination of Total Soluble Protein}

The total soluble protein content of G. jamesonii callus showed differences depending on the gamma irradiation doses. Protein content from each treatment was obtained from protein standard curve plotted in Figure 1. The results showed that soluble protein content in non-irradiated fresh callus was reduced during day 3 of treatment with $67.4 \pm 0.8 \mu \mathrm{g} / \mathrm{g}$ (Table 2). However, soluble protein content started to increase during day 5,7 and 9 of the treatment. After day 9, soluble protein content was reported to reduce and during day 15 , soluble protein content in non-irradiated callus was reduced to $54.5 \pm 2.5 \mu \mathrm{g} / \mathrm{g}$. It could be observed that, in the irradiated callus tissues, almost similar result was obtained where after day 9 of exposure to Gamma irradiation, gradual reduction of soluble protein content was seen. The reduction of soluble protein content was observed in all the treatments (exposure from 10 to $60 \mathrm{~Gy}$ ) as the incubation day increased to day 15 of treatment. Comparing the total protein content of the control callus and 10 Gy irradiated callus, the control callus exhibited significantly greater than those of 10 Gy irradiated callus. There was an irregular distribution of total soluble protein content in the irradiated and non-irradiated callus as the incubation period increased. The callus irradiated at 20 Gy exhibited slightly higher total soluble protein content, $69.9 \pm 0.8 \mu \mathrm{g} / \mathrm{g}$ compared to non-irradiated callus incubated at day 5 with $69.2 \pm 1.7 \mu \mathrm{g} / \mathrm{g}$. Moreover, callus irradiated at 20, $30,40,50$ and 60 Gy showed increase in the total soluble protein content during day 5. However, the callus irradiated at $10 \mathrm{~Gy}$ showed a gradual reduction of total soluble protein content. Gamma irradiation significantly influences the cell metabolism and protein synthesis in the plant meristem cells (Casarett 1968). According to Bajaj (1970), gamma irradiation caused inhibition of the tissue culture growth along with the failure of RNA, and subsequently of protein synthesis. This accounted for the lower protein concentration in the callus tissues of $G$. jamesonii irradiated at high dosage. Both DNA and RNA were lower in the irradiated barley seeds and there was no clear explanation on the effect of irradiation on protein synthesis (Constantin and Love 1967; Bajaj 1970; Posner 1965).

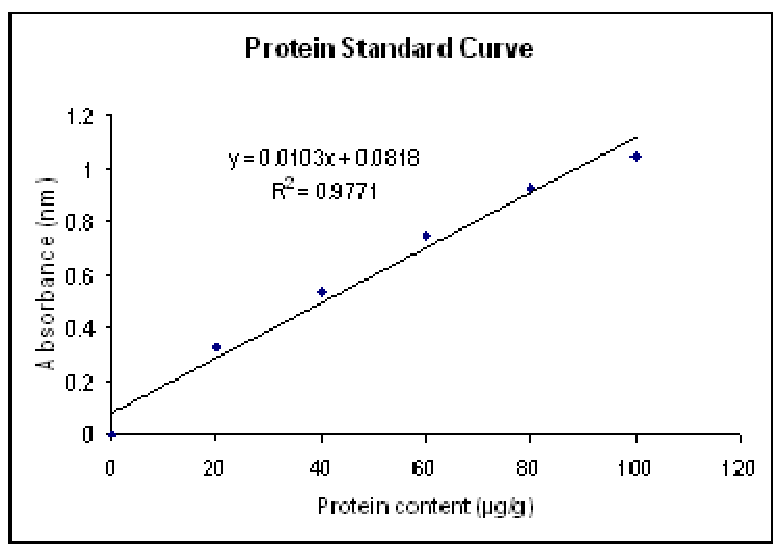

Figure 1- Protein Standard Curve 
Table 2- Soluble Protein Content ( $\mu \mathrm{g} / \mathrm{g}$ of fresh weight) in Irradiated Callus of Gerbera jamesonii at different doses of Gamma Irradiation.

\begin{tabular}{cccccccc}
\hline Days & \multicolumn{7}{c}{ Soluble Protein Content $(\boldsymbol{\mu g} / \mathbf{g}$ of fresh weight) } \\
\cline { 2 - 8 } & $\mathbf{0}$ Gy (control) & $\mathbf{1 0 ~ G y}$ & $\mathbf{2 0 ~ G y}$ & $\mathbf{3 0} \mathbf{~ G y}$ & $\mathbf{4 0 ~ G y}$ & $\mathbf{5 0 ~ G y}$ & $\mathbf{6 0 ~ G y}$ \\
\hline $\mathbf{0}$ & $74.7 \pm 1.2_{\mathrm{a}}$ & - & - & - & - & - & - \\
$\mathbf{3}$ & $67.4 \pm 0.8_{\mathrm{b}, \mathrm{c}}$ & $69.8 \pm 1.5_{\mathrm{b}}$ & $67.7 \pm 0.6_{\mathrm{b}, \mathrm{c}}$ & $66.5 \pm 1.2_{\mathrm{b}, \mathrm{c}}$ & $64.0 \pm 0.3_{\mathrm{b}, \mathrm{c}}$ & $62.5 \pm 0.7_{\mathrm{c}}$ & $61.6 \pm 1.2_{\mathrm{c}}$ \\
$\mathbf{5}$ & $69.2 \pm 1.7_{\mathrm{b}}$ & $68.7 \pm 1.3_{\mathrm{b}}$ & $69.9 \pm 0.8_{\mathrm{b}}$ & $68.3 \pm 1.2_{\mathrm{b}}$ & $67.1 \pm 0.4_{\mathrm{b}, \mathrm{c}}$ & $64.1 \pm 1.5_{\mathrm{b}, \mathrm{c}}$ & $62.1 \pm 0.7_{\mathrm{c}}$ \\
$\mathbf{7}$ & $69.6 \pm 2.2_{\mathrm{b}}$ & $66.2 \pm 0.7_{\mathrm{b}, \mathrm{c}}$ & $67.0 \pm 0.8_{\mathrm{b}, \mathrm{c}}$ & $67.6 \pm 1.1_{\mathrm{b}, \mathrm{c}}$ & $68.1 \pm 0.5_{\mathrm{b}}$ & $66.5 \pm 0.3_{\mathrm{b}, \mathrm{c}}$ & $65.0 \pm 1.2_{\mathrm{b}, \mathrm{c}}$ \\
$\mathbf{9}$ & $69.9 \pm 1.4_{\mathrm{b}}$ & $65.2 \pm 0.9_{\mathrm{b}, \mathrm{c}}$ & $67.8 \pm 0.9_{\mathrm{b}, \mathrm{c}}$ & $66.5 \pm 1.5_{\mathrm{b}, \mathrm{c}}$ & $67.1 \pm 2.1_{\mathrm{b}, \mathrm{c}}$ & $66.4 \pm 1.8_{\mathrm{b}, \mathrm{c}}$ & $65.7 \pm 1.6_{\mathrm{b}, \mathrm{c}}$ \\
$\mathbf{1 1}$ & $63.0 \pm 2.2_{\mathrm{c}}$ & $62.9 \pm 0.4_{\mathrm{c}}$ & $63.7 \pm 0.2_{\mathrm{c}}$ & $62.8 \pm 0.7_{\mathrm{c}}$ & $61.5 \pm 2.2_{\mathrm{c}}$ & $61.3 \pm 0.6_{\mathrm{c}}$ & $60.8 \pm 2.5_{\mathrm{c}}$ \\
$\mathbf{1 3}$ & $59.72 \pm 1.8_{\mathrm{d}}$ & $60.2 \pm 3.2_{\mathrm{c}}$ & $61.1 \pm 2.8_{\mathrm{c}}$ & $60.3 \pm 1.8_{\mathrm{c}}$ & $59.6 \pm 0.7_{\mathrm{d}}$ & $58.3 \pm 0.9_{\mathrm{d}}$ & $57.0 \pm 1.9_{\mathrm{d}}$ \\
$\mathbf{1 5}$ & $54.5 \pm 2.5_{\mathrm{d}}$ & $55.0 \pm 1.7_{\mathrm{d}}$ & $55.5 \pm 1.6_{\mathrm{d}}$ & $54.8 \pm 0.9_{\mathrm{d}}$ & $54.1 \pm 1.3_{\mathrm{d}}$ & $53.6 \pm 2.4_{\mathrm{d}}$ & $52.7 \pm 1.4_{\mathrm{d}}$ \\
\hline
\end{tabular}

Mean \pm SE, $n=30$. Mean with different letters in the same column differ significantly at $p=0.05$

Jordan et al. (1992) observed a decline in the total soluble proteins in pea plants after 3 days of UV-B irradiation whereas in other species, including a different cultivar of corn, the protein content did not change (Basiouny et al. 1978). Tiburcio et al. (1985) reported that the soluble protein level in Nicotiana rustica plants compared to the control plant or just irradiated plants was higher, indicating that stimulatory effect on the increase of soluble protein content could be due to posttreatment recovery.

In corn seeds, Cherry et al. (1961) noted that the production of reducing sugar, protein, soluble nucleotides and RNA was reduced by X-ray irradiation and indicated that this reduction was parallel to growth reduction. Kuzin (1956) and Hagen and Gunckel (1958) found a depression of protein synthesis in Nicotiana glauca and Nicotiana langsdorfu caused by the radiation. Mcglasson and Lee (1971) also reported that irradiation caused a breakdown of protein in tomato fruit. Vasilyev (1962) observed an increase in the protein synthesis in a variety of plant species a few days after the irradiation.

Humera (2006) stated that the stress reaction of the plants often resulted in the alteration of protein metabolism. Several proteins are synthesized and accumulated in plant tissues under a range of stress conditions. Such proteins, referred to a stress protein, have been noted to be induced in response to several stress factors. The most crucial function of the plant cell is to respond to gamma stress by developing defenses mechanisms. This defense was brought about by the alteration in the pattern of gene expression. Owing to gene expression altered under gamma stress, qualitative and quantitative changes in the total soluble protein content was obvious (Corthals et al. 2000). Kume and Matsuda (1995) stated that radiation causes the irreversible changes of protein conformation at the molecular level by the breakage of covalent bonds of polypeptide chains.

Previous studies have shown that there was no consistent report regarding the effect of irradiation on the nucleic acids, protein and nitrogen. Some researchers have observed slight depression or increase, while others reported no significance changes. Constantin and Love (1967) observed a slight decrease in the protein of gamma irradiated Vigna sinensis seedlings. Pollard (1964) reported that irradiation stopped the DNA transcription and lead to a decrease in the protein synthesis and growth. He added that in Chlorella pyrenoidosa, the cells exposed for 3 days to gamma irradiation increased in volume and had increased amount of DNA and protein (per cell). The irradiation can effect protein directly and indirectly (Gunkel and Sparrow 1954), whereby protein synthesis is inhibited (Cherry et al. 1961), unaffected or enhanced (Clark and Fernandes 1961).

In conclusion, the radio sensitivity of the plants might be essentially due to the genetical make-up of a race, and it could be modified by the physical or physiological conditions of the plant material. Gamma irradiation showed significant effect in influencing the amount of chlorophyll and soluble protein content in the irradiated callus tissues of Gerbera jamesonii Bolus ex. Hook f. This showed that radiation effects could produce superior qualities mutants, exhibiting useful and applicable somaclonal variations in the morphological aspects of $G$. jamesonii. Hence, more economical varieties could be produced. 


\section{ACKNOWLEDGEMENTS}

The authors would like to thank The Institute of Research Management and Monitoring (IPPP) of University Malaya, Kuala Lumpur, Malaysia for the research grant PS 301/2009B and Physics Department, Faculty of Science, University of Malaya, Kuala Lumpur, Malaysia for providing gamma irradiation source.

\section{REFERENCES}

Ahloowalia BS, Maluszynski M. Induced mutations- A new paradigm in plant breeding, Euphytica. 2001; 118: 167-173.

Bajaj YPS. Effect of gamma irradiation on growth, RNA protein and nitrogen contents of bean callus cultures. Ann botany 1970; 34: 1089-1096.

Basiouny FM, Van TK, Biggs RH. Some morphological and biochemical characteristics of $\mathrm{C} 3$ and $\mathrm{C} 4$ plant irradiated with UV-B. Physiol Plant. 1979; 42: 29-32.

Bradford M. A rapid and sensitive method for the quantification of microgram quantities of protein utilizing the principle of protein-dye binding. Anal Biochem. 1976; 72: 248-254.

Broertjes C. Mutagen treatment and handling of treated material. In: Manual on Mutation breeding. Second edition, International Atomic Agency, Tech. Rep. Ser. No 119. Vienna $; 1977$.

Casarett AP. Radiation Chemistry. Prentice Hall, Inc., Englewood, New Jersey; 1968.

Cherry JH, Hageman RH, Collins FI, Flesher D. Effects of X-radiation on corn seed. Plant Physiol.1961; 36: 566572.

Clark TD, Fernandes SJG. The effect of y-irradiation on the protein content of apples and pears. Int $J$ Appl Radiat Isot. 1961; 11: 186-189.

Constantin MS, Love JE. Seedling responses of Vigna sinensis of gamma and neutron seed irradiation. Radiat Bot. 1967; 7: 497-506.

Corthals G, Gygi S, Aebersold R, Patterson SD. Identification of proteins by mass spectrometry. Proteome Res. 2000; 2: 286-290.

Giacomelli M, Donini MLB, Cervigni T. Effects of kinetin on chlorophyll breakdown and protein levels in irradiated barley leaves. Radiat. Bot. 1967; 7: 375-385.

Gunkel JE, Sparrow AH. Aberrant growth in plants induced by ionizing radiation. Brookhaven Symp. Biol. 1954; 6: 252-279.

Hagen GL, Gunckel JE. Free amino-acid levels following gamma irradiation of Nicotiana glauca, N. Langsdorfii and their intermediate specific hybrid. Plant Physiol. 1958; 33: 439-443.

Humera A. Biochemical and molecular markers of somaclonal variants and induced mutants of potato (Solanum tuberosum L.) [PhD Thesis], Lahore, Pakistan: University of the Punjab; 2006.
Jordan BR, He J, Chow WA, Anderson JM. Changes in mRNA levels and polypeptide subunits of ribulose 1,5bisphosphate carboxylase in response to supplementary UV-B radiation. Plant Cell Environ.1992; 15: 91-98.

Kim JH, Baek MH, Chung BY, Wi SG, Kim JS. Alterations in the photosynthetic pigments and antioxidant machineries of red pepper (Capsicum annuиm L.) seedlings from gamma-irradiated seeds. $J$ Plant Biotechnol. 2004; 47: 314-321.

Kume T, Matsuda T. Changes in structural and antigenic properties of proteins by radiation. Radiat. Phys. Chem. 1995; 46: 225-231.

Kuzin AM. Biochemical fundamentals of the biological action of ionizing radiation. In: Kuzin, A.M. (ed.) Rev Radiobiol, Press of the Acad. of Sci. USSR, Moscow; 1956. p. 4-125 (English translation).

Lichtenthaler HK. Chlorophylls and carotenoids: pigments of photosynthetic biomembranes. Enzymol. 1987; 148: 350-381.

Maluszynski M, Ahloowalia BS, Sigurbjornsson B. (1995), Application of in vivo and in vitro mutation techniques for crop improvement. Euphytica. 1995; 85; 303-315.

Maluszynski M, Sigurbjornsson, B, Amano E, Sitch L, Kamra O. Mutant varieties data bank, FAO, IAEA database. Part II. Mutation Breed Newsl. 1992; 39: 1417.

Mcglasson WB, Lee TH. Damage and repair of protein in gamma irradiated tomato fruit. Radiat. Bot. 1971; 11: 239-241.

Murashige T, Skoog F. A revised medium for rapid growth and bioassays with tobacco tissue cultures. Physiol. Plant. 1962; 15: 473-497.

Pollard E. Ionizing radiation: Effect of genetic transcription. Science. 1964; 145: 710-711.

Posner HB. Effects of gamma irradiation on growth, colony-forming ability and some cellular constituents of Chlorella pyrenoidosa. Radiat. Bot. 1965; 5: 129-141.

Powell RD, Griffiths MM. Effects of kinetin, red light and gamma radiation on growth of disks of bean leaves. Bot Gaz. 1963; 124: 274-278.

Stove N. Physiological effects of the synthetic growth regulator Thidiazurol (drop) on gamma-irradiated stress in peas plants (Pisum sativum). J Cent Eur Agr.2002; 6: 349-358.

Strid A, Chow WS, Anderson JM. Effects of supplementary gamma irradiation on photosynthesis in Pisum sativum. Biochem. 1990; 1020: 260-268.

Tiburcio AF, Pinol MT, Serrano M. Effect of UV-C on growth, soluble protein and alkaloids in Nicotiana rustica plants. Env Exp Bot. 1985; 25: 203-210.

Vasilyev IM. Effects of Ionizing Radiations on Plants. AEC-tr 5836 Biology and Medicine, United States Atomic Energy Commission; 1962. p. 40-46.

Received: February 25, 2011; Revised: June 21, 2011; Accepted: March 09, 2012. 